\title{
Opioids Mobilize Calcium from Inositol 1,4,5-Trisphosphate-Sensitive Stores in NG108-15 Cells
}

\author{
Wenzhen Jin, Nancy M. Lee, Horace H. Loh, and Stanley A. Thayer \\ Department of Pharmacology, University of Minnesota Medical School, Minneapolis, Minnesota 55455
}

Opioids elicit an increase in the intracellular free $\mathrm{Ca}^{2+}$ concentration $\left(\left[\mathrm{Ca}^{2+}\right]_{i}\right)$ in neuroblastoma $\times$ glioma hybrid NG 10815 cells, which, depending upon growth conditions, results from either $\mathrm{Ca}^{2+}$ influx in differentiated cells or $\mathrm{Ca}^{2+}$ release from internal stores in undifferentiated cells (Jin et al., 1992). In this report we describe fura-2-based digital imaging studies that demonstrate that opioid-evoked $\mathrm{Ca}^{2+}$ release in these cells results from the activation of phospholipase $C$ (PLC) and subsequent mobilization of the inositol 1,4,5-trisphosphate $\left(\mathrm{IP}_{3}\right)$-sensitive store. D-Ala ${ }^{2}-\mathrm{D}-\mathrm{Leu}^{5}$-enkephalin (DADLE) evoked concentration-dependent increases in $\left[\mathrm{Ca}^{2+}\right]_{\text {, }}$ $\left(E C_{50} \cong 4 \mathrm{~nm}\right.$ ). The response was blocked by naloxone (1 $\mu \mathrm{M})$. In single cells, sequential application of selective opioid agonists (10 $\mathrm{nM}$ ) evoked responses of the rank order DADLE $=\mathrm{D}-\mathrm{Pen}^{2}, \mathrm{D}-\mathrm{Pen}^{5}$-enkephalin (DPDPE) > trans-(+) 3,4-dichloro- $N$-methyl- $N$-(2-[1-pyrrolidinyl] cyclohexyl) benzeneacetamide (U50488) > D-ala ${ }^{2}, \mathrm{~N}$-Me-Phe ${ }^{4}$, Gly5-ol-enkephalin (DAMGO), consistent with activation of a $\delta$-opioid receptor. Forty percent $(n=198)$ of the cells responded to $100 \mathrm{~nm}$ DADLE with a net $\left[\mathrm{Ca}^{2+}\right]_{i}$ increase of $483 \pm 40 \mathrm{nM}$. Bradykinin $(100 \mathrm{~nm})$ elicited a response in $91 \%$ of the cells with a mean net amplitude of $707 \pm 36 \mathrm{~nm}$. The DADLE-evoked responses were not blocked by removal of extracellular $\mathrm{Ca}^{2+}$; instead, they were abolished by treatment with $10 \mathrm{nM}$ thapsigargin, an agent that depletes and prevents refilling of $\mathrm{IP}_{3}$-sensitive $\mathrm{Ca}^{2+}$ stores. A $1 \mu \mathrm{M}$ concentration of U73122, an aminosteroid inhibitor of PLC, completely blocked the DADLE-evoked $\left[\mathrm{Ca}^{2+}\right]_{i}$ increase, while an inactive analog, U73433, was without effect. To explore the possible role of G-proteins in mediating opioid-induced $\left[\mathrm{Ca}^{2+}\right]_{i}$ increases in NG108-15 cells, we pretreated cells with pertussis or cholera toxin; pertussis toxin blocked the opioid-induced response while cholera toxin was without effect, consistent with $a_{i} G_{i}-$ or $G_{0}$-mediated effect. Activation of the opioid inhibitory pathway previously described for these cells appears to stimulate the phosphoinositide (PI) cascade as well. Including the PI cascade among the multiple second messenger systems modulated

\footnotetext{
Reccived May 7, 1993; revised Nug. 3, 1993; accepted Oct. 14, 1993.

This work was supported by NIDA Research Grants DA-05695 (H.H.L.), K05 DA-00020 (N.M.L.), DA-00564 (H.H.L.), DA-01583 (H.H.L.), DA-02643 (N.M.L.), K05-DA-70554 (II.I.L.), DA-06781 (S.A.T.), and DA-07304 (S.A.T.), and Grant BNS9010486 (S.A.T.) from the National Science Foundation. H.H.L. is the Alice and Frederick Stark Professor. S.A.T. is a University of Minnesota McKnight-Land Grant Professor.

Correspondence should be addressed to S. A. Thayer, Department of Pharmacology, University of Minnesota Medical School, 3-249 Millard Hall, 435 Delaware Street S.E., Minneapolis, MN 55455.

Copyright (C) 1994 Society for Neuroscience $0270-6474 / 94 / 141920-10 \$ 05.00 / 0$
}

by opioids may be key to understanding the biochemical events that underlie acute and chronic opioid action.

[Key words: intracellular calcium, opioids, NG108-15, phospholipase $C$, thapsigargin, U73122]

Opioid receptors couple via G-proteins to inhibit voltage-sensitive $\mathrm{Ca}^{2+}$ channels (Gross and Macdonald, 1984; Hescheler et al., 1987; Surprenant et al., 1990; Jin et al., 1993) and to activate $\mathrm{K}^{-}$channels (Werz and Macdonald, 1983; Christie et al., 1987). These inhibitory actions underlie the decrease in neurotransmitter release and reduced cellular excitability produced by opioids (Duggan and North, 1984). Opioid receptors also negatively couple to adenylyl cyclasc (Sharma et al., 1975a), though the resultant effects on neuronal excitability are less clear (Wang and Aghajanian, 1987). To our knowledge, opioid receptor coupling to the phosphoinositide (PI) cascade has not been demonstrated, though recent reports suggest that such a coupling may exist. Opioids potentiate NMDA currents via a mechanism blocked by a selective inhibitor of protein kinase $\mathrm{C}$ (Chen and Huang, 1991), yel allempts to measure opioid-induced increases in PI breakdown products have generally been negative (Yu and Sadee, 1986; but see Periyasamy and Hoss, 1990).

Recent studies indicate that many neurotransmitters previously thought to play purely inhibitory roles, such as GABA (Hahner et al., 1991), adenosine (Okada et al., 1992), calcitonin gene-related peptide (Wiley et al., 1992), and neuropeptide $Y$ (Wiley et al., 1991), also exert excitatory effects. These effects have been ascribed to either of two mechanisms. In some cases an additional receptor subtype has been discovered; one subtype selectively produces inhibition and the other produces excitation. Alternatively, a single receptor may couple to multiple second messenger systems exerting excitatory or inhibitory effects depending on the state of the cell (Bourne and Nicoll, 1993).

Both excitatory and inhibitory effects of opioids have been observed. At the cellular level, opioid effects on cell excitability are generally inhibitory, though neuronal networks, depending on the circuitry, can be disinhibited by opioids producing gross excitation (Zieglgansberger et al., 1979; Madison and Nicoll, 1988; Neumaier et al., 1988). In sensory neurons, opioids exert both inhibitory as well as direct excitatory effects (Crain and Shen, 1990). We have found that opioids elicit a direct excitatory effect in NG108-15 cells that is manifest as an increase in the

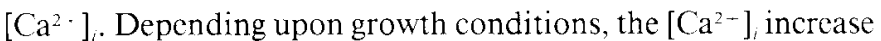
results from either $\mathrm{Ca}^{2+}$ influx in differentiated cells or $\mathrm{Ca}^{2+}$ relcase from internal stores in undifferentiated cells (Jin et al., 1992). In this report we have studied the opioid-induced $\mathrm{Ca}^{2+}$ mobilization in more detail. We find that opioids activate phos- 


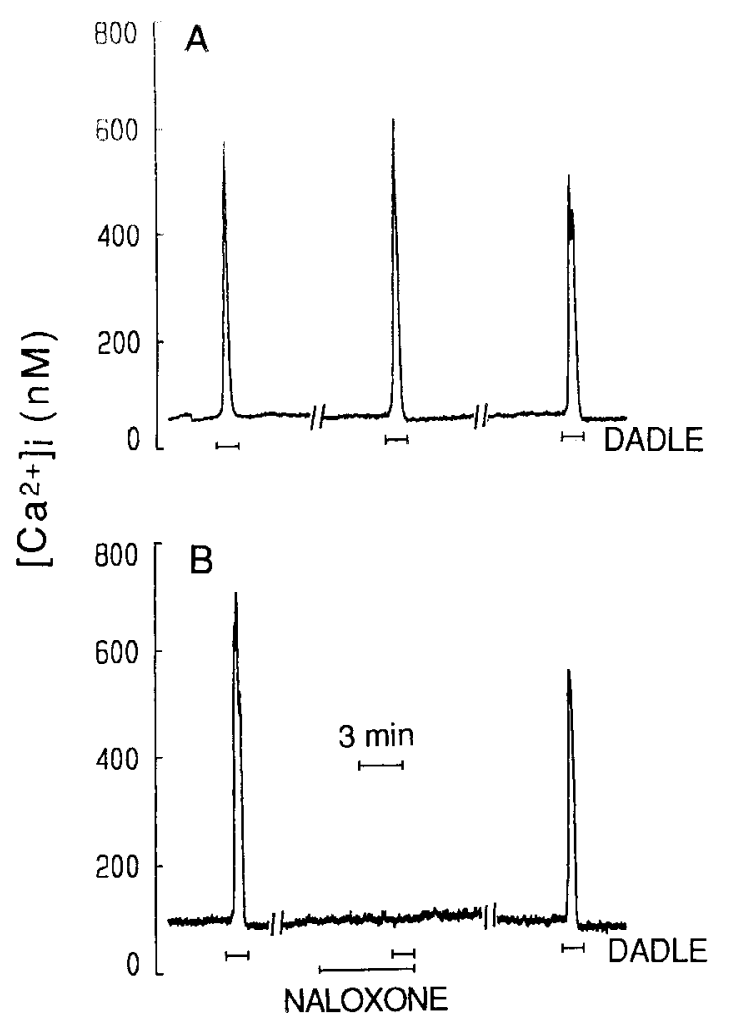

Figure 1. DADLE-induced $\left[\mathrm{Ca}^{2+}\right]$ increases are mediated by opioid receptors. $A$, Reproducible DADLE-induced $\left[\mathrm{Ca}^{2+}\right]_{i}$ transients were elicited by superfusion with $100 \mathrm{nM}$ DADLE for $90 \mathrm{sec}$ at $25 \mathrm{~min}$ intervals $(n=6) . B$, The DADLE-induced response was blocked reversibly by 1 $\mu \mathrm{M}$ naloxone $(n=3)$. Drugs were applied as indicated by the horizontal bars. $\left[\mathrm{Ca}^{2+}\right]_{i}$ was measured in single NG108-15 cells by indo-1-based photometry.

pholipase $\mathrm{C}$ (PLC), resulting in a subsequent release of $\mathrm{Ca}^{2+}$ from an inositol 1,4,5-trisphosphate $\left(\mathrm{IP}_{3}\right)$-sensitive store.

\section{Materials and Methods}

Materials. Materials were purchased from the following companies: fura-2 acetoxymethyl ester (AM) and indo-1 AM, Molecular Probes, Eugene, OR; U73122 and U73433, Biomol Research Laboratories, Inc., Plymouth Meeting, PA; pertussis toxin (PTX) and cholera toxin (CTX), List Biological Laboratories, Inc., Campbell, CA; D-Ala' ${ }^{2}$ D-Leu ${ }^{5}-\mathrm{en}-$

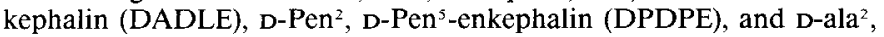
$\mathrm{N}$-Me-Phe ${ }^{4}, \mathrm{Gly}^{5}$-ol-enkephalin (DAMGO), Peninsula Laboratories, Inc., Belmont, CA; U50488, Upjohn Laboratories, Kalamazoo, MI; thapsigargin, LC Service Corp., Woburn, $\mathrm{MA} ; \mathrm{CO}_{2}$-independent media, GIBCO Labs, Grand Island, NY; all other reagents, Sigma, St. Louis, MO.

Cell culture. NG108-15 cells (passages 20-30) were grown in culture as previously described (Jin et al., 1992). Stock cultures were maintained in Dulbecco's Modified Eagle's Medium (DMEM) supplemented with $5 \%$ fetal bovine serum, $0.1 \mu \mathrm{M}$ hypoxanthine, $10 \mu \mathrm{M}$ aminopterine, 17 $\mu \mathrm{M}$ thymidine in a humidified atmosphere of $90 \%$ air and $10 \% \mathrm{CO}_{2}$. Cells from the stock cultures were plated onto glass coverslips $(25 \mathrm{~mm}$ round) at a density of $3 \times 10^{4}$ cells/coverslip and grown for 6-9 d in $\mathrm{CO}_{2}$-independent media (phosphate rather than bicarbonate buffered) supplemented with $5 \mu \mathrm{M}$ forskolin.

Experimental procedure. NG108-15 cells were incubated in either 2 $\mu \mathrm{M}$ indo- $1 \mathrm{AM}$, for photometry, or $2 \mu \mathrm{M}$ fura- $2 \mathrm{AM}$, for digital imaging, in HEPES-buffered Hank's salt solution containing $0.5 \%$ bovine serum albumin for $45-60 \mathrm{~min}$ at $37^{\circ} \mathrm{C}$. Hank's buffer was composed of the following (in mM): HEPES, 20; $\mathrm{NaCl}, 137 ; \mathrm{CaCl}_{2}, 1.3 ; \mathrm{MgSO}_{1}, 0.4$; $\mathrm{MgCl}_{2}, 0.5 ; \mathrm{KCl}, 5.0 ; \mathrm{KH}_{2} \mathrm{PO}_{4}, 0.4 ; \mathrm{Na}_{2} \mathrm{HPO}_{4}, 0.6 ; \mathrm{NaHCO}_{3}, 3.0$; and glucose, 5.6. The cover glass was then mounted in a flow-through chamber (Thayer et al., 1988) that was superfused at a rate of $2 \mathrm{ml} / \mathrm{min}$ and placed on the stage of the microfluorimeter. Loading was terminated

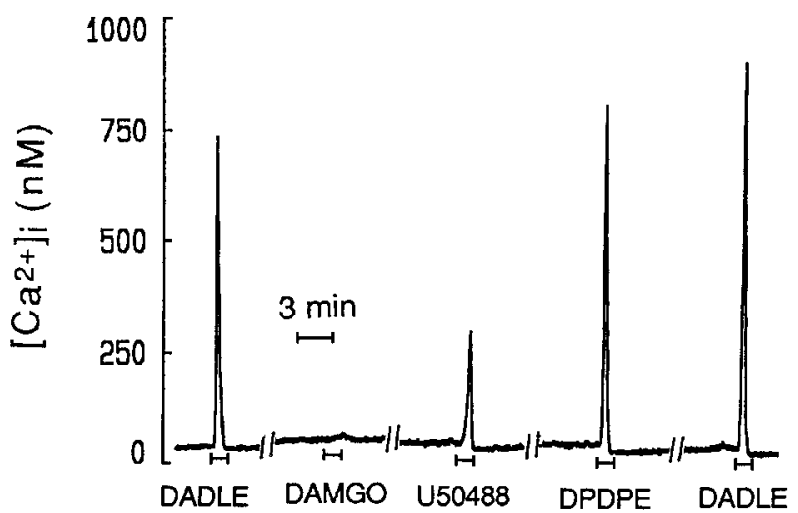

Figure 2. The DADLE-induced $\left[\mathrm{Ca}^{2+}\right]_{i}$ increase is mediated by $\delta$-opioid receptors. Opioid agonists ( $10 \mathrm{nM})$ were sequentially superfused onto an NG108-15 cell during the times indicated by the horizontal bars. Recording is representative of four experiments in which the rank order of potency, DADLE $=$ DPDPE $>$ U50488 > DAMGO, was observed. Diagonal lines indicate gaps in the recording; agonists were applied at 25 min intervals.

by washing with Hank's buffer for 20-30 min prior to starting an experiment. Solutions were selected with a multiport valve coupled to several reservoirs. $\mathrm{CaCl}_{2}$ was replaced with $20 \mu \mathrm{M} \mathrm{EGTA}$ for $\mathrm{Ca}^{2+}$-free experiments.

Photometry. We have previously described our instrumentation for indo-1-based dual emission microfluorimetry and its calibration (Jin et al., 1992).

Digital imaging. The chamber containing the fura-2-loaded cells was mounted on the stage of an inverted microscope (Nikon Diaphot) and alternately excited at 340 or $380 \mathrm{~nm}$ by rapidly switching optical filters (10 $\mathrm{nm}$ band pass) mounted in a computer-controlled wheel (Sutter Instrument, Inc.) placed between a $75 \mathrm{~W}$ Xe arc lamp and the epifluorescence port of the microscope. Excitation light was reflected from a dichroic mirror $(400 \mathrm{~nm})$ through a $90 \times$ objective (Leitz; NA 1.15). Fluorescent images $(510,40 \mathrm{~nm}$ band pass) were projected $(0.5 \times)$ onto a cooled CCD camera (Photometrics, Inc.; $384 \times 576$ binned to 192 $\times 288$ pixels) controlled by an 80486 (DX2/66) computer. Image pairs were collected every $6.2 \mathrm{sec}$; exposure to excitation light was always less than $100 \mathrm{msec}$ per image and the interval between paired images was $385 \mathrm{msec}$

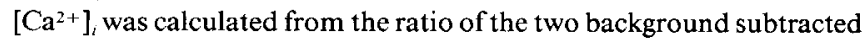
digital images. Cells were delimited by producing a mask that contained pixel values above a threshold applied to the $380 \mathrm{~nm}$ image. Background images were collected at the conclusion of each experiment after removing cells from the coverslip. Autofluorescence from cells not loaded with the dye was less than $5 \%$ and thus not corrected. Ratio values were converted to free $\left[\mathrm{Ca}^{2+}\right]_{i}$ by the equation $\left[\mathrm{Ca}^{2+}\right]_{i}=K \beta\left(R-R_{\min }\right) /\left(R_{\max }\right.$ $-R$ ), in which $R$ is the $340: 380 \mathrm{~nm}$ fluorescence emission ratio and $K$ $=224 \mathrm{nM}$, the dissociation constant for fura-2 (Grynkiewicz et al., 1985). The maximum ratio $\left(R_{\max }=2.93\right)$, the minimum ratio $\left(R_{\min }=0.16\right)$, and the constant $\beta$ (the ratio of the fluorescence measured at $380 \mathrm{~nm}$ in $\mathrm{Ca}^{2+}$-free and saturating solution; 6.7) were determined by treating cells with $10 \mu \mathrm{M}$ ionomycin in $\mathrm{Ca}^{2+}$-free ( $1 \mathrm{~mm}$ EGTA) and saturating $\left(5 \mathrm{mM} \mathrm{Ca}^{2+}\right)$ solution.

\section{Results}

NG108-15 cells were grown in serum-free, $\mathrm{CO}_{2}$-independent media supplemented with $5 \mu \mathrm{M}$ forskolin for 6-9 d. Elevating cAMP levels in NG108-15 cells grown in DMEM will induce the cells to differentiate. In contrast, the cells used in this study extend very short, if any, processes and lack a significant depolarization-induced increase in $\left[\mathrm{Ca}^{2+}\right]_{i}$, and thus by these criteria are undifferentiated. Treatment of these cells with $100 \mathrm{nM}$ DADLE for $90 \mathrm{sec}$ evoked a $\left[\mathrm{Ca}^{2+}\right]_{i}$ increase that rose at least $50 \mathrm{~nm}$ above the resting level in $33 \%$ of the cells $(n=114)$. In previous studies (Jin et al., 1992) we grew cells in standard bicarbonate-based media (DMEM) and found that only $10 \%$ of 
the undifferentiated cells responded with an increase in $\left[\mathrm{Ca}^{2+}\right]_{\text {, }}$. While attempting to enhance this low frequency of response we experimented with $\mathrm{CO}_{2}$-independent growth media, which, in combination with forskolin, reproducibly generated cultures with a response frequency greater than $30 \%$. In responding cells, $\left[\mathrm{Ca}^{2+}\right]$, increased from an average basal level of $83 \pm 4 \mathrm{~nm}$ to a net amplitude of $648 \pm 87 \mathrm{~nm}$ as indicated by indo-1-based dual emission photometry (Fig. 1A). Reproducible responses could be elicited by applying DADLE at 25 min intervals (peak $2 /$ peak $1=95 \pm 16 \%$ ). We employed this paradigm to determine the nature of the receptor mediating these responses. Naloxone $(1 \mu \mathrm{M})$ blocked completely and reversibly the DADLE-evoked responses (Fig. $1 B ; n=3$ ), indicating that the DADLE-induced increases in $\left[\mathrm{Ca}^{2+}\right]$, were mediated by opioid receptors. To determine which opioid receptor type mediated the $\left[\mathrm{Ca}^{2+}\right]_{i}$ increase, we performed agonist selectivity studies. Figure 2 shows the $\left[\mathrm{Ca}^{2+}\right]_{i}$ increases elicited by sequential application of selective opioid agonists (10 nM) to the same cell. The observed rank order of potency, DADLE $=$ DPDPE $>$ U50488H $>$ DAMGO, is consistent with activation of the $\delta$-opioid receptor. This finding is consistent with radioligand binding studies in undifferentiated NG108-15 cells in which a homogeneous population of $\delta$-opioid receptors was found (Law et al., 1985). Complete characterization of the receptor will require complete concentration-response curves for the agonists.

In order to study the DADLE-induced $\left[\mathrm{Ca}^{2+}\right]_{i}$ increases more efficiently, we employed fura- 2 based digital imaging in order to record responses from a population of cells simultaneously (Fig. 3). Fields of 6-12 cells were selected for recording (Fig. $3 \mathrm{~A}$ ). When challenged with $100 \mathrm{~nm}$ DADLE for $90 \mathrm{sec}, 40 \%$ (79 of 198) of the cells responded with a $\left[\mathrm{Ca}^{2+}\right]_{i}$ increase of at least $50 \mathrm{~nm}$, in good agreement with the frequency of responding cells recorded individually with photometry (Fig. $3 B$, frames $1-$ 7). Subsequent superfusion of the cells with $100 \mathrm{~nm}$ bradykinin for $1 \mathrm{~min}$ induced a large increase in $\left[\mathrm{Ca}^{2+}\right]_{i}$ in $91 \%$ (242 of 267 ) of the NG108-15 cells (Fig. 3B, frames 8-14). Cells responded to DADLE with an average increase in $\left[\mathrm{Ca}^{2}\right]_{i}$ of 483 $\pm 40 \mathrm{nM}$, which is only $68 \%$ of the average peak response to bradykinin $(707 \pm 36 \mathrm{~nm})$. Both DADLE- and bradykininevoked peak $\left[\mathrm{Ca}^{2+}\right]_{i}$ values recorded with digital imaging were somewhat smaller than those recorded with photometry, presumably due to the slower sampling rate employed for imaging studics. In Figure $3 C$ plots of $\left[\mathrm{Ca}^{2+}\right]_{i}$ versus time are shown for cells representing those that responded to both DADLE and bradykinin (green squares) as well as cells that failed to respond to DADLE but did respond to bradykinin (red squares). It appears that the $\mathrm{PLC} \beta 1 / \mathrm{IP}_{3}$ pathway is functional in virtually all of these cells while only a subset respond to DADLE. The amplitude of the bradykinin-induced $\left[\mathrm{Ca}^{2+}\right]_{t}$ increase in those cells that responded to DADLE may have been attenuated because of insufficient time to refill $\mathrm{Ca}^{2+}$ stores between stimuli.

DADLE elicited increases in $\left[\mathrm{Ca}^{2+}\right]$, over the concentration range of 1-30 nM (Fig. 4). Maximal responses were typically obtained at $30 \mathrm{nM}(n=19$; four experiments), in good agreement with opioid-induced direct excitatory effects previously described in thesc (Jin et al., 1992) and other cell types (Crain and Shen, 1990; Gintzler and Xu, 1991). The excitatory effect described here occurs at opioid concentrations several orders of magnitude lower than those required for inhibition of $\mathrm{Ca}^{2+}$ channels in these cells (Hescheler et al., 1990; Kasai, 1992; Jin et al., 1993). The $\mathrm{EC}_{50}$ for DADLE was approximately $4 \mathrm{~nm}$ (Fig. $4 D$ ), which is in good agreement with the $\mathrm{EC}_{50}$ for DADLEevoked $\mathrm{Ca}^{2+}$ influx in differentiated NGl08-15 cells.

We have previously described opioid-induced $\mathrm{Ca}^{2+}$ influx in differentiated NG108-15 cells (Jin et al., 1992); however, the DADLE-induced increases in $\left[\mathrm{Ca}^{2+}\right]_{i}$ described in this report result from the release of $\mathrm{Ca}^{2+}$ from an intracellular store. As shown in Figure $5 A$, removal of extracellular $\mathrm{Ca}^{2+}$ had little effect on the amplitude of the DADLE-induced $\left[\mathrm{Ca}^{2+}\right]$, transient (representative of six of seven cells). In one experiment the response was inhibited significantly such that in the absence of extracellular $\mathrm{Ca}^{2+}$ the average response amplitude was $62 \pm$ $16 \%$ (peak 2 peak $1 ; n=7$ ), which is smaller than control responses (Fig. 1.A; $95 \pm 16 \%$ ). Clearly, the majority of the response results from $\mathrm{Ca}^{2+}$ derived from an intracellular pool. Since the $\mathrm{IP}_{3}$-sensitive store is a likely candidate for $\mathrm{Ca}^{2+}$ mobilization resulting from activation of plasmalemmal receptors (Berridge, 1993), and NG108-15 cells possess large $\mathrm{IP}_{3}$-sensitive $\mathrm{Ca}^{2+}$ stores (Lo and Thayer, 1993), we explored the possibility that opioids might be releasing this store. Thapsigargin inhibits the $\mathrm{Ca}^{2-} / \mathrm{Mg}^{2+}$-ATPase responsible for sequestering $\mathrm{Ca}^{2+}$ into $\mathrm{IP}_{3}$-sensitive stores (Thastrup et al., 1990). In NG108-15 cells, $10 \mathrm{~nm}$ thapsigargin will deplete and prevent irreversibly the refilling of the $\mathrm{IP}_{3}$-sensitive $\mathrm{Ca}^{2+}$ store (Lo and Thayer, 1993). In Figure $5 B$ we show that thapsigargin mobilized $\mathrm{Ca}^{2+}$ from an intracellular store and prevented all subsequent DADLEelicited responses ( $90 \pm 8 \%$ inhibition; $n=5)$, consistent with the idea that DADLE is releasing $\mathrm{Ca}^{2+}$ from the $\mathrm{IP}_{3}$-sensitive $\mathrm{Ca}^{2+}$ store.

DADLE-induced mobilization of the $\mathrm{IP}_{3}$-sensitive store suggests that opioids stimulate PI hydrolysis in NG108-15 cells. To test this hypothesis we treated NG108-15 cells with the PLC inhibitor U73122. We have shown previously that a $20 \mathrm{~min}$ incubation with $1 \mu \mathrm{M} U 73122$ will completely block the PLCmediated $\mathrm{Ca}^{2}$ mobilization stinulated by bradykinin in NG10815 cells (W. Jin, T.-M. Lo, H. H. Loh, and S. A. Thayer, unpublished observations). A close structural analog, L73343, was without effect on bradykinin-induced $\mathrm{Ca}^{2}$ mobilization. Superfusion of $1 \mu \mathrm{M}$ U73122 for 20 min completely blocked DADLE-induced $\mathrm{Ca}^{2+}$ mobilization (Fig. $6 A ; n=4$ ). In contrast, the inactive analog $\mathrm{U} 73343$ did not affect the DADLE-induced $\left[\mathrm{Ca}^{2+}\right]$ transient (Fig. $6 B ; n=3$ ).

DADLE, acting with high affinity on opioid receptors, apparently activates PLC, leading to the subsequent mobilization of the $\mathrm{IP}_{3}$-sensitive $\mathrm{Ca}^{2}$ store. Yet opioid receptors in NG10815 cells are thought to couple to $\mathrm{G}_{\mathrm{o}}$ and $\mathrm{G}_{\mathrm{i}}$, which do not activate PLC $\beta 1$ via their $\alpha$ subunits (Hepler and Gilman, 1992). Inhibitory heterotrimeric G-proteins have been shown to stimulate

\footnotetext{
Figure 3. DADLE and bradykinin increase $\left[\mathrm{Ca}^{2 *}\right]$, in NG108-15 cells. $A$, Bright-field image of NG108.15 cells grown in $\mathrm{CO}_{2}$-independent media supplemented with $5 \mu \mathrm{m}$ forskolin for $6 \mathrm{~d}$. Areas used for calculating $\left[\mathrm{Ca}^{2+}\right.$ ] were defined by a mask determined from the $380 \mathrm{~nm}$ fluorescence image and are delimited by the yellow border. $B$, Pseudocolor representations of $\left[\mathrm{Ca}^{2+}\right]$, were derived from fura-2-based digital images and scaled as shown in $C$. The images displayed in $B$ were acquired at the times indicated by the frame numbers along the plot in $C$. $C$, [Ca ${ }^{2}{ }^{2}$, values from the areas circumscribed by the rectangles in $A$ are plotted versus time. Representative responses are shown for a cell that responded to both DADLE and bradykinin (green squares) and a cell that responded to bradykinin only (red squares). Sequential ratio pairs were collected every 6.2 sec. The cells were superfused with $100 \mathrm{~nm}$ DADLE for $90 \mathrm{sec}$ or $100 \mathrm{~nm}$ bradykinin $(B K)$ for $60 \mathrm{sec}$ as indicated by the horizontal bars in $C$.
} 

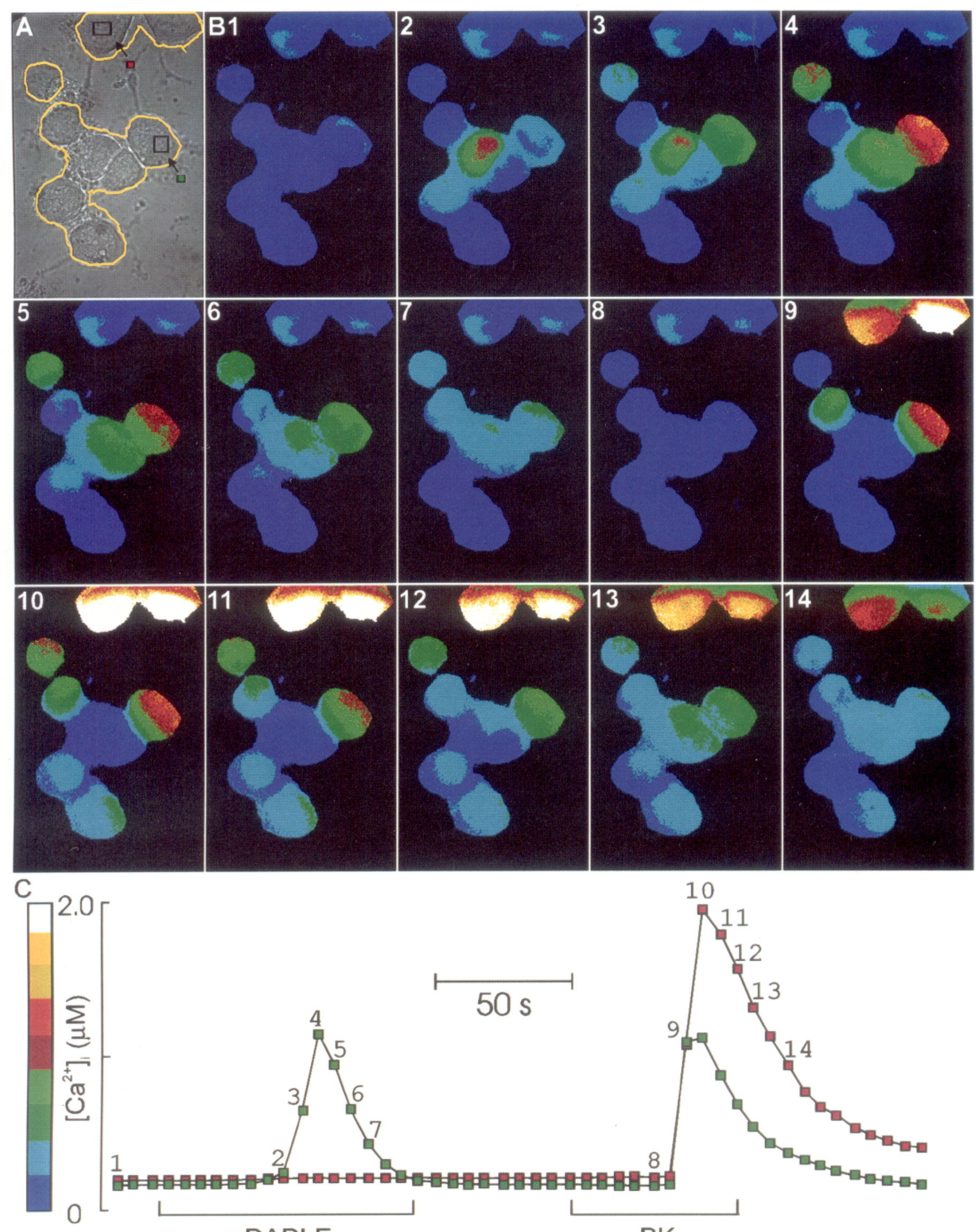

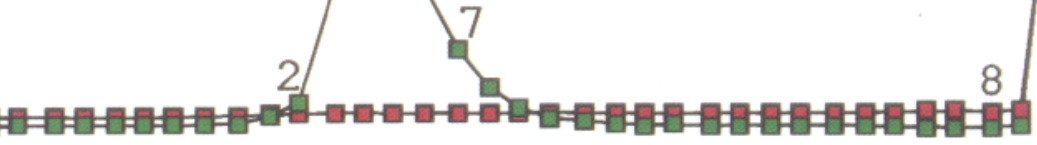

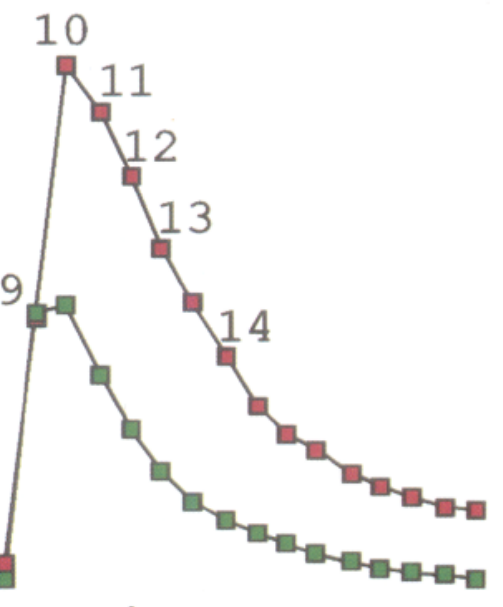

DADLE

BK 
PLC $\beta 2$ via their $\beta \gamma$ subunits (Camps et al., 1992; Katz et al., 1993). We examined DADLE- and bradykinin-induced responses after inactivation of specific populations of G-proteins with CTX or PTX (Fig. 7). The frequency of responses greater than $50 \mathrm{~nm}$ in this cohort of untreated cultures was $42 \%(n=$ 106) for DADLE and $93 \%$ for bradykinin. Pretreatment with 1 $\mu \mathrm{g} / \mathrm{ml} \mathrm{CTX}$ for $4 \mathrm{hr}$ failed to inhibit the $\left[\mathrm{Ca}^{2+}\right]_{i}$ increase evoked by either DADLE or bradykinin (Fig. $7 A$ ). In contrast, pretreatment of the cultures for $24 \mathrm{hr}$ with $100 \mathrm{ng} / \mathrm{ml}$ PTX blocked the DADLE-evoked $\left[\mathrm{Ca}^{2}{ }^{+}\right]_{i}$ increase, but the bradykinin-induced response remained intact (Fig. $7 B$ ), consistent with $\mathrm{G}_{0}$ or $\mathrm{G}_{i}$ mediating the opioid response and $\mathrm{G}_{\mathrm{q}}$ mediating the bradykinin response. These data are summarized in Figure $7 C$. After treatment with CTX, $38 \%$ and $87 \%$ of the cells responded to DADLE and bradykinin, respectively. Treatment with PTX significantly reduced the number of cells responding to DADLE to $10 \%$ ( $p$ $<0.005$ ), while the percentage of cells responding to bradykinin remained unaffected $(88 \%)$. $\delta$ opioid receptors in NG108-15 cells have been shown previously to inhibit adenylyl cyclase via $G_{1}$ and to inhibit $\mathrm{Ca}^{2+}$ channels via $\mathrm{G}_{o}$ (Hsia et al., 1984; Hescheler et al., 1987). Neither CTX nor PTX treatment affected the bradykinin-induced response, consistent with the idea that the bradykinin receptor couples to PLC $\beta 1$ by $\alpha_{q} ; \mathrm{G}_{\mathrm{q}}$ is not sensitive to PTX (Hepler and Gilman, 1992).

\section{Discussion}

We have found that activation of opioid receptors by DADLE activates a PTX-sensitive G-protein resulting in a subsequent stimulation of $\mathrm{PI} C$ and mobilization of $\mathrm{Ca}^{2+}$ from an $\mathrm{IP}_{3}$-sensitive store. These data provide a biochemical explanation for the opioid-induced increases in $\left[\mathrm{Ca}^{2+}\right]_{i}$ we (Jin et al., 1992) and others (Okajima and Kondo, 1992) have described previously in NG108-15 cells. Activation of the PI cascade may also underlie the opioid-induced enhancement of NMDA-activated currents in spinal neurons (Chen and Huang, 1991), but probably not the CTX-sensitive prolongation of the action potential by opioids in sensory neurons (Shen and Crain, 1990).

The DADLE-induced increase in $\left[\mathrm{Ca}^{2+}\right]_{i}$ was blocked by naloxone, which is consistent with a response mediated by an opioid receptor. The rank order of potency for selective agonists, DADLE $=$ DPDPE $>$ U50488 $>$ DAMGO, is consistent with activation of a $\delta$ receptor. Additionally, the effect was elicited by nanomolar concentrations of DADLE, suggesting that the $\left[\mathrm{Ca}^{2+}\right]_{i}$ increase results from an interaction of high affinity. The $\mathrm{EC}_{50}$ of approximately $4 \mathrm{nM}$ is in good agreement with the 1.9 nм $K_{d}$ for DADLE in radioligand binding assays (Law et al., 1985 ) and the $2.9 \mathrm{nM} \mathrm{IC}_{50}$ for inhibition of adenylyl cyclase (Law et al., 1982) in these cells. Inhibition of $\mathrm{Ca}^{2+}$ channels by opioids has generally required micromolar concentrations (Hescheler et al., 1990; Kasai, 1992; Jin et al., 1993; but sec Tsunoo ct al., 1986). Extensive concentration-response data for opioid inhibition of $\mathrm{Ca}^{2+}$ currents are not available and the rather high concentrations of opioids used to inhibit whole-cell $\mathrm{Ca}^{2+}$ currents may be necessitated by the need to elicit rapid and maximal inhibition to discern modulation of the currents from channel rundown. Interestingly, opioid-induced excitatory effects, manifest as action potential broadening in dorsal root ganglion neurons, were detected at opioid concentrations 2 orders of magnitude lower than those required to elicit inhibitory effects in the same cells (Shen and Crain, 1989). Excitatory effects have been reported for a number of neurotransmitters previously thought to clicit purely inhibitory actions. In the cases of neuropeptide $Y$ and adenosine the excitatory effect has been clearly attributed to the discovery of an additional, excitatory receptor subtype (Wiley et al., 1991; Okada et al., 1992). NG108-15 cells are thought to possess only $\delta$ opioid receptors (Law et al., 1985). The existence of multiple $\delta$ receptor subtypes has been suggested (Sofunglu et al., 1990), but at present subtype-selective drugs are not available to test the hypothesis that a novel $\delta$ receptor subtype mediates the excitatory effects of opioids in NG108-15 cells.

In NG108-15 cells, opioid receptor coupling to $\mathrm{Ca}^{2+}$ channels and adenylyl cyclase has been shown previously to be mediated by $G_{w}$ and $G_{i}$ type G-proteins (Hescheler et al., 1987; Costa et al., 1988; Beech et al., 1992). The effective inhibition of the opioid-induced $\mathrm{Ca}^{2+}$ mobilization by PTX suggests that opioid coupling to PLC may employ one of these same previously characterized inhibitory G-proteins. This result is in contrast to the opioid-induced excitatory responses in sensory neurons (Shen and Crain, 1990) and F11 cells (Fan et al., 1993), which were blocked by CTX. To our knowledge, there is no evidence suggesting that $\alpha_{1}$ is capable of activating PLC directly. However, $\beta \gamma$ subunits liberated by the activation heterotrimeric $G_{i}$ could stimulate PLC $\beta 2$ (Katz et al., 1993). The small amplitude of the DADLE-induced $\left[\mathrm{Ca}^{2+}\right]_{i}$ transients is consistent with less robust $\mathrm{IP}_{3}$ production observed for $\mathrm{G}_{\mathrm{i}}$ - and $\mathrm{G}_{\mathrm{o}}$-mediated versus $\mathrm{G}_{\mathrm{q}}$-mediated PLC activation. In Xenopus oocytes expressing muscarinic $m 3$ receptors, which couple to $G_{q}$, stimulation with agonist resulted in increases in $\left[\mathrm{Ca}^{2-}\right]$, that were large, rapid, and transient. In contrast, stimulation of $m 2$ receptors, which couple to $\mathrm{G}_{i}$, produced modest increases in $\left[\mathrm{Ca}^{2+}\right]_{i}$ that were slow, oscillatory, and focal (Lechleiter et al., 1991). Calcitonin gene-related peptide and $\mathrm{GABA}_{\mathrm{B}}$ receptors provide additional examples of receptors that activate inhibitory G-proteins to produce excitatory effects in addition to their inhibitory actions (Hahner et al., 1991; Wiley et al., 1992).

There is circumstantial evidence suggesting a link between opioid receptors and PLC. For example, in spinal trigeminal neurons opioid-induced increases in NMDA currents can be blocked by a selective protein kinase $\mathrm{C}$ inhibitor (Chen and Huang, 1991). This effect may underlie opioid-mediated induction of long-term potentiation (Derrick et al., 1992). In NG108-15 cells the PLC inhibitor U73122 (Bleasdale et al., 1990) effectively blocked DADLE-induced increases in $\left[\mathrm{Ca}^{2+}\right]_{\text {. }}$. We have shown previously that U73122 will completely block bradykinin-induced $\left[\mathrm{Ca}^{2+}\right]_{i}$ increases in these cells (Jin, Lo, Loh, and Thayer, unpublished observations), a response previously shown to be mediated by PLC (Brown and Higashida, 1988). The selectivity of U73122 for PLC has not been fully established. Our confidence in the conclusion that U73122 blocked

Figure 4. Nanomolar DADLE concentrations elicit $\left[\mathrm{Ca}^{2+}\right]_{i}$ increases in NG108-15 cells. Pseudocolor representations of $\left[\mathrm{Ca}^{2+}\right]_{i}$ were derived from fura-2-based digital images and scaled as shown. The same field of NG108-15 cells was treated with $1 \mathrm{nM}(A), 3 \mathrm{nM}(B)$, and $10 \mathrm{nM}(C)$ DADLE. DADLE was applied for $90 \mathrm{sec}$ at $25 \mathrm{~min}$ intervals. Resting $\left[\mathrm{Ca}^{2+}\right]_{i}$ levels were determined (frame 1), then the cells were treated with DADLE and $\left[\mathrm{Ca}^{2-}\right]$, and images were recorded $32 \mathrm{sec}$ (frame 2), $38 \mathrm{sec}$ (frame 3), $57 \mathrm{sec}$ (frame 4), and $82 \mathrm{sec}$ (frame 5) later. Bath exchange required approximately $10 \mathrm{sec} . D$, Data from four experiments are summarized; the response at each concentration is the mean $\pm \mathrm{SE}$ of at least 18 cells. 


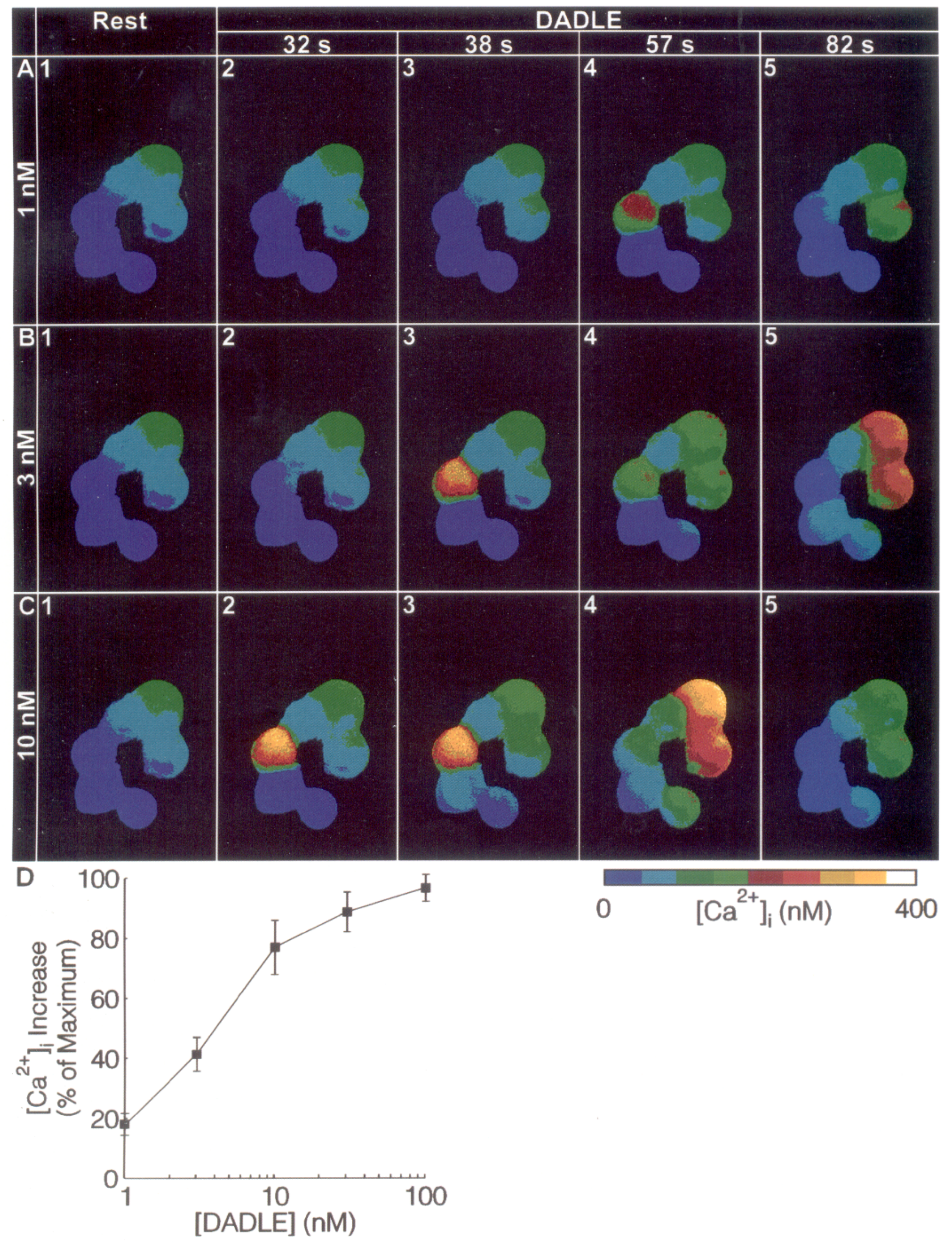




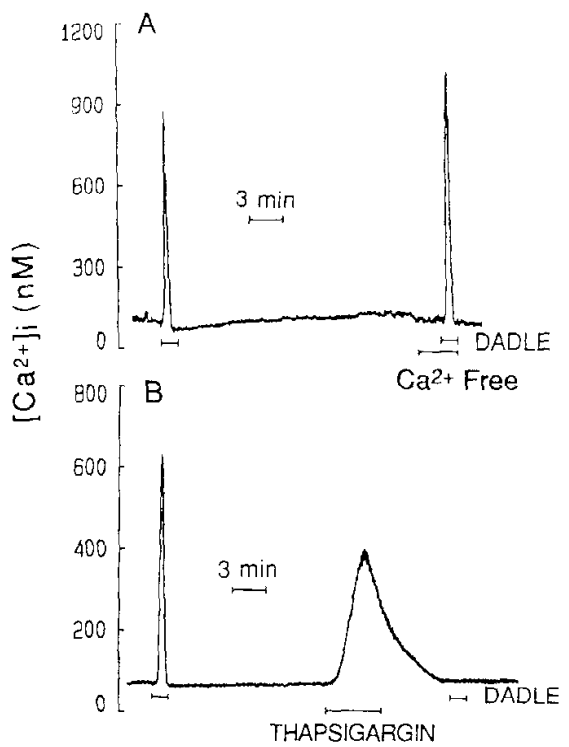

Figure 5. DADLE releases $\mathrm{Ca}^{2+}$ from the $\mathrm{IP}_{3}$-sensitive store. $A$, The DADLE-induced $\left.(100 \mathrm{nM}) \mathrm{CCa}^{2+}\right]$, transient was not significantly diminished in the absence of extracellular $\mathrm{Ca}^{2+}(n=6)$. $B$, Thapsigargin at $10 \mathrm{~nm}$ released $\mathrm{Ca}^{2+}$ from an intracellular store and prevented a subsequent response to DADLE $(n=5)$. Drugs were applied at the times indicated by the horizontal bars [ $\mathrm{Ca}^{2+}$ ], was measured in single NG10815 cells by indo-1-based photometry.

DADLE-induced responses by inhibition of PLC is bolstered by failure of the inactive structural analog 173343 to inhibit the opioid response, as well as the results of our thapsigargin and $\mathrm{Ca}^{2+}$-free experiments that implicate the $\mathrm{IP}_{3}$-sensitive store. Thapsigargin has been widely used and has proven very selective for inhibition of $\mathrm{Ca}^{2+} / \mathrm{Mg}^{2+}$-ATPase isoforms found only on intracellular $\mathrm{Ca}^{2}$ stores (l'hastrup et al., 1990; Lo and Thayer, 1993).

Attempts to measure PI breakdown products have generally been negative (Yu and Sadee, 1986; but see Periyasamy and Hoss, 1990). Previous attempts to detect opioid-induced increases in $\mathrm{IP}_{3}$ may have failed because biochemical methods lack the sensitivity to detect a modest increase produced by opioids. The $\left[\mathrm{Ca}^{2+}\right]_{i}$ increases we observed were both small, approximately $32 \%$ smaller than those elicited by bradykinin, and heterogeneous: only $33-40 \%$ of the cells responded with an increase in $\left[\mathrm{Ca}^{2+}\right]$. Thus, techniques that average across a population of cells are at a distinct disadvantage for detecting the response. In addition, we have used unique cell culture conditions to optimize the detection of opioid-induced $\left[\mathrm{Ca}^{2+}\right]_{i}$ increases. The observation that growth conditions can increase the number of responding cells argues against the idea that the heterogeneity results from divergence of what is thought to be a clonal cell line.

In previous studies we found that DADLE-induced $\left[\mathrm{Ca}^{2 !}\right]_{i}$ increases resulted from $\mathrm{Ca}^{2+}$ influx in differentiated cells and resulted from $\mathrm{Ca}^{3+}$ mobilization in undifferentiated cells. The cells used in this study extend very short, if any, processes and lack a significant depolarization-induced increase in $\left[\mathrm{Ca}^{2+}\right]$, and thus by our criteria are undifferentiated. We speculate that during differentiation, which in some respects models neuronal development (Hamprecht et al., 1985), the opioid-stimulated PI hydrolysis switches from a response dominated by $\mathrm{Ca}^{2+}$ release from the $\mathrm{IP}_{3}$-sensitive store to one predominantly resulting

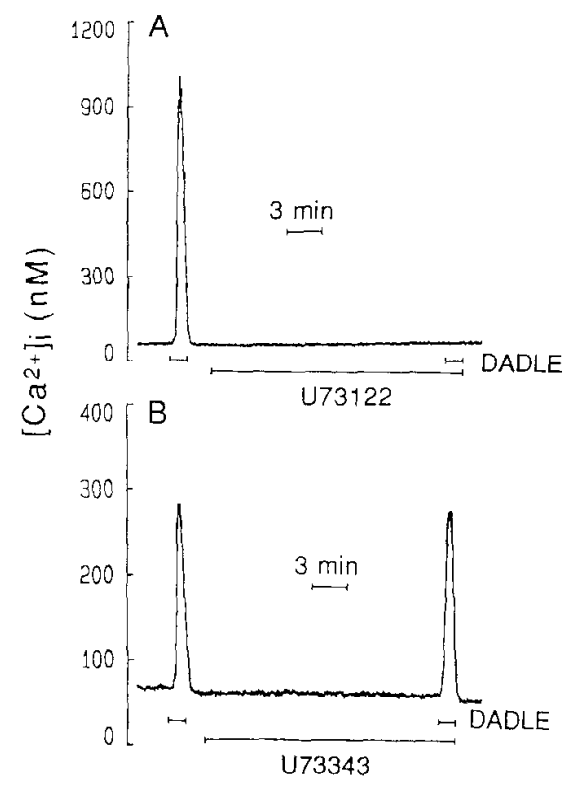

Figure 6. DADLE activates PLC to mobilize $\mathrm{Ca}^{2+}$ from the $\mathrm{LP}_{3}$-sensitive store. The PLC inhibitor $\operatorname{U73122}(n=4 ; A)$ and its inactive analog $\mathrm{U} 73343(n=3 ; B)$ were superfused onto single NG1087-15 cells during the times indicated by the horizontal bars. DADLE (100 nM), IJ73122 (1 $\mu \mathrm{M})$, and $1773343(1 \mu \mathrm{M})$ were applied during the times indicated by the horizontal bars. [ $\mathrm{Ca}^{2+}$ ], was measured in single NG $108-$ 15 cells by indo-1-based photometry.

from a depolarization-induced response mediated by diacylglycerol activation of protein kinase $\mathrm{C}$ and subsequent $\mathrm{Ca}^{2+}$ influx. We have not, as yet, determined the ionic currents that underlie $\mathrm{Ca}^{2}$ influx in differentiated cells, but a dependence on extracellular $\mathrm{Na}^{+}$is consistent with $\mathrm{C}$ kinase activation of an $\mathrm{Na}^{+}$ conductance. Activation of $\mathrm{P}_{2}$ purinoceptors increases a depolarizing conductance carried primarily by $\mathrm{Na}^{+}$, providing precedent for such a mechanism (Shen and North, 1993). Protein kinase $\mathrm{C}$ will also modify voltage-gated $\mathrm{Ca}^{2+}$ channels directly (Yang and Tsion, 1993). The growth conditions that produce the greatest yield of responding cells, whether differentiated (DMEM) or undifferentiated $\left(\mathrm{CO}_{2}\right.$-independent media), included chronic elevation of cAMP by treatment with forskolin. Thus, cross talk between the CAMP and PI second messenger systems may be required to permit opioid-induced $\left[\mathrm{Ca}^{2+}\right]$, increases. There is a precedent for state-dependent activation of adenylyl

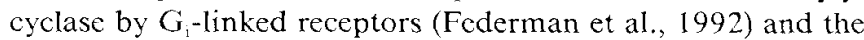
importance of such biochemical coincidence detectors has been reviewed (Bourne and Nicoll, 1993). One of the results of chronic treatment of NG108-15 cells with opioids is a compensatory increase in adenylyl cyclase activity (Sharma et al., 1975b), raising the interesting possibility that during chronic treatment with opioids, opioid receptor coupling to the PI cascade may become more pronounced.

Indeed, chronic treatment of dorsal root ganglion neurons with opioids increases the number of cells with opioid-induced excitatory responses and greatly decreases the threshold for eliciting opioid-induced excitatory responses in these cells (Crain et al., 1988; Shen and Crain, 1992). The molecular and cellular changes that result from chronic treatment with opioids have not presented a clear picture. In NG108-15 cells chronic opioids will produce a downregulation of receptors and a corresponding increase in the activity of adenylyl cyclase (Smith et al., 1988), 

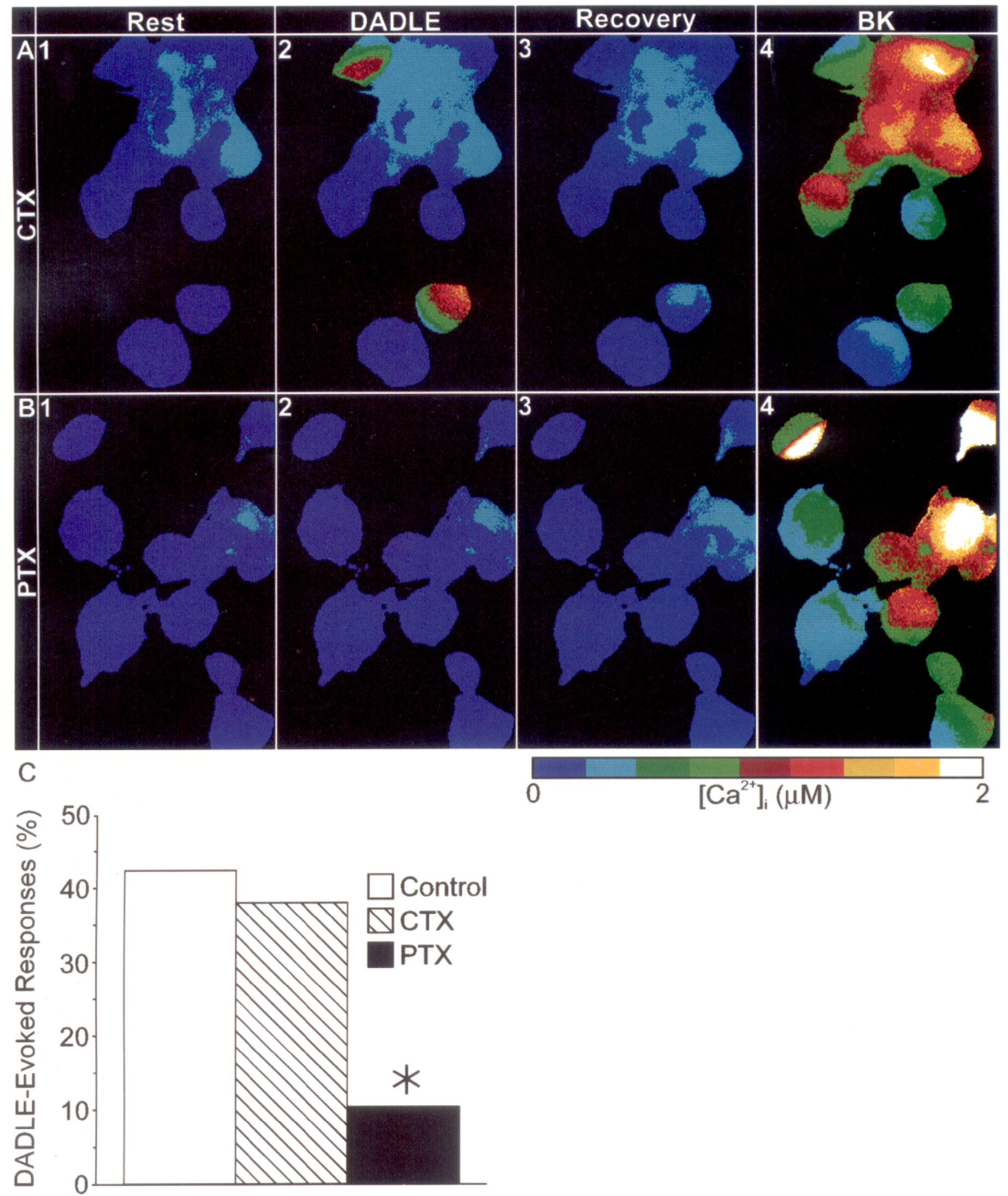

Figure 7. DADLE-induced $\left[\mathrm{Ca}^{2+}\right]_{i}$ increases are mediated by a PTX-sensitive G-protein. Cultures were pretreated with either CTX $(1 \mu \mathrm{g} / \mathrm{ml}, 4$ $\mathrm{hr} ; A)$ or PTX $(100 \mathrm{ng} / \mathrm{ml}, 24 \mathrm{hr} ; B)$. Resting $\left[\mathrm{Ca}^{2+}\right]_{i}$ levels were determined in the cells (frame 1), which were then superfused with $100 \mathrm{~nm}$ DADLE for $90 \mathrm{sec}$ (frame 2), allowed to recover for $1 \mathrm{~min}$ (frame 3), and finally challenged with $100 \mathrm{~nm}$ bradykinin for 60 sec (frame 4 ). Pseudocolor representations of $\left[\mathrm{Ca}^{2+}\right]$, were derived from fura-2-based digital images and scaled as shown. Data from untreated $(n=106)$, CTXtreated $(n=71)$, and PTX-treated $(n=96)$ cultures are summarized in $C .{ }^{*}$, The frequency of DADLE-evoked responses in PTX-treated cells was significantly different from untreated sister cultures $\left(p<0.005, \chi^{2}\right.$ test). 
yet in vivo, gross changes in receptor number have not been detected and relating cAMP levels to electrical activity has not been straightforward. We believe that the possibility that chronic exposure to opiates unmasks excitatory actions of these drugs warrants testing.

We have shown that activation of opioid receptors in the neuronal cell line NG108-15 will activate PLC resulting in subsequent release of $\mathrm{Ca}^{2+}$ from intracellular stores. We speculate this effect can be generalized to primary tissue. Including the PI cascade among the multiple second messenger systems modulated by opioids may be helpful in clarifying the biochemica: events which accompany acute and chronic opioid action.

\section{References}

Beech D, Bernheim L, Hille B (1992) Pertussis toxin and voltage dependence distinguish multiple pathways modulating calcium channels of rat sympathetic neurons. Neuron 8:97-106.

Berridge MJ (1993) Inositol trisphosphate and calcium signaling. Nature 361:315-325.

Bleasdale JE, Thakur NR, Gremban RS, Bundy GL, Fitzpatrick FA, Smith RJ, Bunting S (1990) Selective inhibition of receptor-coupled phospholipase $\mathrm{C}$-dependent processes in human platelets and polymorphonuclear neutrophils. J Pharmacol Exp Ther 255:756-768.

Bourne HR, Nicoll R (1993) Molecular machines integrate coincident synaptic signals. Neuron 10:65-75.

Brown DA, Higashida H (1988) Membrane current responses of NG108-15 mouse neuroblastoma $\times$ rat glioma hybrid cells to bradykinin. J Physiol (Lond) 397:167-184.

Camps M, Carozzi A, Schnabel P, Scheer A, Parker PJ, Gierschik P (1992) Isozyme-selective stimulation of phospholipase $\mathrm{C}-\beta 2$ by $\mathrm{G}$ protein $\beta \gamma$-subunits. Nature 360:684-686.

Chen L, Huang L-YM (1991) Sustained potentiation of NMDA receptor-mediated glutamate responses through activation of protein kinase $C$ by a $\mu$ opioid. Neuron 7:319-326.

Christie MJ, Williams JT, North RA (1987) Cellular mechanisms of opioid tolerance: studies in single brain neurons. Mol Pharmacol 32: 633-638.

Costa T, Klinz F, Vachon L, Herz A (1988) Opioid receptors are coupled tightly to $\mathrm{G}$ proteins but loosely to aderrylate cyclase in NG10815 cell membranes. Mol Pharmacol 34:744-754.

Crain SM, Shen KF (1990) Opioids can evoke direct receptor-mediated excitatory effects on sensory neurons. Trends Pharmacol Sci 11 : $77-81$.

Crain SM, Shen K-F, Chalazonitis A (1988) Opioids excite rather than inhibit sensory neurons after chronic opioid exposure of spinal cordganglion cultures. Brain Res 455:99-109.

Derrick BE, Rodriguez SB, Lieberman DN, Martinez JL (1992) Mu opioid receptors are associated with the induction of hippocampal mossy fiber long-term potentiation. J Pharmacol Exp Ther 263:725733.

Duggan AW, North RA (1984) Electrophysiology of opioids. Pharmacol Rev 35:219-281.

Fan SF, Shen K-F, Crain SM (1993) $\mu$ and $\delta$ opioid agonists at low concentrations decrease voltage-dependent $\mathrm{K}^{+}$currents in F1 1 neuroblastoma $\times D R G$ hybrid cells via cholera toxin-sensitive receptors. Brain Res 605:214-220.

Federman AD, Conklin BR, Schrader KA, Reed RR, Bourne HR (1992) Hormonal stimulation of adenylyl cyclase through $\mathrm{G}_{i}$-protein $\beta \gamma$ subunits. Nature 356:159-161.

Gintzler AR, Xu H (1991) Different G proteins mediate the opioid inhibition or enhancement of evoked [5-methionine] enkephalin release. Proc Natl Acad Sci USA 88:4741-4745.

Gross RA, Macdonald RL (1984) Dynorphin a selectively reduces a large transient ( $\mathrm{N}$-type) calcium current of mouse dorsal root ganglion neurons in cell culture. Neurobiology 84:5469-5473.

Grynkiewicz G, Peonie M, Tsien RY (1985) A new generation of calcium indicators with greatly improved fluorescence properties. J Biol Chem 260:3440-3450.

Hahner L, Mcquilkin S, Harris RA (1991) Cerebellar GABAb receptors modulate function of GABAa receptor. FASEB J 5:2466-2472.

Hamprecht B, Glaser T, Reiser G, Bayer E, Propst F (1985) Culture and characteristics of hormone-responsive neuroblastoma $\times$ glioma hybrid cells. Methods Enzymol 109:316-341.

Hepler JR, Gilman AG (1992) G proteins. Trends Biochem Sci 17: 383-387.

Hescheler J, Rosenthal W, Trautwein W, Schultz G (1987) The GTPbinding protein, $\mathrm{G}_{\mathrm{o}}$, regulates neuronal calcium channels. Nature 325 : 445-447.

Hescheler J, Krautwurst D, Schultz G, Trautwein W (1990) Calcium currents of neuroblastoma $\times$ glioma hybrid cells after cultivation with dibutyryl cyclic AMP and nickel. Eur J Physiol 417:329-335.

Hsia JA, Moss J, Hewlett EL, Vaughan M (I 984) ADP-ribosylation of adenylate cyclase by pertussis toxin: effects on inhibitory agonist binding. J Biol Chem 259:1086-1090.

Jin W, Lee NM, Loh HH, Thayer SA (1992) Dual excitatory and inhibitory effects of opioids intracellular calcium in neuroblastoma $\times$ glioma hybrid NG108-15 cells. Mol Pharmacol 42:1083-1089.

Jin W, Lee NM, Loh HH, Thayer S (1993) Opioid-induced inhibition of voltage-gated calcium channels parallels expression of $\omega$-conotoxin-sensitive channel subtype during differentiation of NG108-15 cells. Brain Res 607:17-22.

Kasai $H$ (1992) Voltage- and time-dependent inhibition of neuronal calcium channels by a GTP-binding protein in a mammalian cell line. J Physiol (Lond) 448:189-209.

Katz A, Wu D, Simon MI (1993) Subunits $\beta \gamma$ of heterotrimeric G protein activate $\beta 2$ isoform of phospholipase C. Nature 360:686-689.

Law PY, Koehler JE, Loh HH (1982) Comparison of opiate inhibition of adenylate cyclase activity in neuroblastoma N18TG2 and neuroblastoma $\times$ glioma NG108-15 hybrid cell lines. Mol Pharmacol 21: 483-491.

Law PY, Hom DS, Loh HH (1985) Multiple affinity states of opiate receptor in neuroblastoma $\times$ glioma NG108-15 hybrid cells. J Biol Chem 260:3561-3569.

Lechleiter J, Giiard S, Clapham D, Peralta E (1991) Subcellular patterns of calcium release determined by $G$ protein-specific residues of muscarinic receptors. Nature 350:505-508.

Lo T-M, Thayer SA (1993) Refilling the inositol 1,4,5-trisphosphatesensitive calcium store in neuroblastoma $\times$ glioma hybrid NGI0815 cells. Am J Physiol 33:C641-C653.

Madison DV, Nicoll RA (1988) Enkephalin hyperpolarizes interneurones in the rat hippocampus. $J$ Physiol (Lond) 398:123-130.

Neumaier JF, Mailheau S, Chavkin C (1988) Opioid receptor-mediated responses in the dentate gyrus and CAl region of the rat hippocampus. J Pharmacol Exp Ther 244:564-570.

Okada Y, Sakuri T, Mori M (1992) Excitatory effect of adenosine on neurotransmission is due to increase of transmitter release in the hippocampal slices. Neurosci Lett 142:233-236.

Okajima F, Kondo Y (1992) Synergism in cytosolic $\mathrm{Ca}^{2+}$ mobilization between bradykinin and agonists for pertussis toxin-sensitive $\mathrm{G}$-protein-coupled receptors in NG 108-15 cells. FEBS Lett 301:223-226.

Periyasamy S, Hoss W (1990) Kappa opioid receptors stimulate phosphoinositide turnover in rat brain. Life Sci 17:219-225.

Sharma SK, Nirenbeg M, Klee WA (1975a) Morphine receptors as regulators of adenylate cyclase activity. Proc Natl Acad Sci USA 72: 590-594.

Sharma SK, Klee WA, Niremberg M (1975b) Dual regulation of adenylate cyclase accounts for narcotic dependence and tolerance. Proc Natl Acad Sci USA 72:3092-3096.

Shen K, Crain S (1989) Dual opioid modulation of the action potential duration of mouse dorsal root ganglion neurons in culture. Brain Res 491:227-242.

Shen KF, Crain SM (1990) Cholera toxin-A subunit blocks opioid excitatory effects on sensory neuron action potentials indicating mediation by $\mathrm{G}_{\mathrm{s}}$-linked opioid receptors. Brain Res 525:225-231.

Shen KF, Crain SM (1992) Chronic selective activation of excitatory opioid receptor functions in sensory neurons results in opivid 'dependence' without tolerance. Brain Res 597:74-83.

Shen KZ, North RA (1993) Excitation of rat locus coeruleus neurons by adenosine 5'-triphosphate: ionic mechanism and receptor characterization. J Neuroscí 13:894-899.

Smith AP, Law P-Y, Loh HH (1988) Role of opioid receptors in narcotic tolerance/dependence. In: The opiate receptors (Pasternak GW, ed), pp 441-485. Clifton, NJ: Humana.

Sofuoglu M, Portoghese PS, Takemori AE (1990) Differential antagonism of delta opioid agonists by naltrindole (NTI) and its benzofuran analog (NTB). J Pharmacol Exp Ther 257:676-680. 
Surprenant AS, Shen K-Z, North RA, Tatsumi H (1990) Inhibition of calcium currents by noradrenaline, somatostatin and opioids in guinea-pig submucosal neurones. J Physiol (Lond) 431:585-608.

Thastrup O, Cullen PJ, Drobak BK, Hanley MR, Dawson AP (1990) Thapsigargin, a tumor promoter, discharges intracellular $\mathrm{Ca}^{2+}$ stores by a specific inhibition of the endoplasmic reticulum $\mathrm{Ca}^{2+}-\mathrm{ATPase}$. Proc Natl Acad Sci USA 87:2466-2470.

Thayer SA, Sturek M, Miller RJ (1988) Measurement of neuronal $\mathrm{Ca}^{2+}$ transients using simultaneous microfluorimetry and electrophysiology. Pfluegers Arch 412:216-223.

Tsunoo A, Yoshii M, Narahashi T (1986) Block of calcium channels by enkephalin and somatostatin in neuroblastoma-glioma hybrid NG108-15 cells. Proc Natl Acad Sci USA 83:9832-9836.

Wang YY, Aghajanian GK (1987) Excitation of locus coeruleus neurons by an adenosine $3^{\prime}, 5^{\prime}$-cyclic monophosphate-activated inward current: extracellular and intracellular studies in rat brain slices. Synapse 1:481-487.

Werz MA, Macdonald RL (1983) Opioid peptides selective for muand delta-opiate receptors reduce calcium-dependent action potential duration by increasing potassium conductance. Neurosci Lett 42:173178.

Wiley JW, Gross RA, Macdonald RL (1991) Neuropeptide (NPY) Y1 and $Y 2$ receptors mediate opposite actions on nodose neuronal calcium currents via pertussis toxin-sensitive pathways. Soc Neurosci Abstr 17:902.

Wiley JW, Gross RA, Macdonald RL (1992) The peptide CGRP increases a high-threshold $\mathrm{Ca}^{2+}$ current in rat nodose neurones via a pertussis toxin-sensitive pathway. J Physiol (Lond) 455:367-381.

Yang J, Tsien RW (1993) Enhancement of N- and L-type calcium channel currents by protein kinase $\mathrm{C}$ in frog sympathetic neurons. Neuron 10:127-136.

Yu VC, Sadee W (1986) Phosphatidylinositol turnover in neuroblastoma cells: regulation by bradykinin, acetylcholine, but not $\mu$ - and $\delta$-opioid receptors. Neurosci Lett 71:219-223.

Zieglgansberger W, French MED, Siggins GR, Bloom FE (1979) Opioid peptides may excite hippocampal pyramidal neurons by inhibiting adjacent inhibitury interneurons. Science 205:415-417. 